\title{
CASE STUDY DESIGN OF A STAND-ALONE PHOTOVOLTAIC POWER SYSTEM IN GAZA-STRIP AND GENARALIZING APROGRAM SIMULATION
}

\section{(Eng.Husam Awad)}

(Palestine Broadcasting Television)

Gaza University /Technical Engineering

Gaza, Palestine

husam20111@gmail.com

\author{
(Mr..Naem Harb) \\ (Palestine Broadcasting Television) \\ TV Producer \&Director \\ Gaza, Palestine \\ Husamawwad2015@hotmail.com
}

\author{
(Dr. Ghada abu Al goboz) \\ (Palestine University) \\ (Instructor and Trainer of projects) \\ Gaza, Palestine \\ g.m.s.a@,hotmail.com
}

\author{
(Eng.Shareif Shurrab) \\ Gaza, Palestine \\ Mechanical Engineering Department \\ (Palestine Broadcasting Television) \\ shareifshurrab@gmail.com
}

\begin{abstract}
This paper considered the design of a stand-alone PV system that would be adequate to power a single residence and estimate the appropriate size of the solar panel. This system converts solar energy directly into electricity using photovoltaic principle in PV panel arrays. The electricity produced can be used to power most ac and dc electrical appliances. Inverter is used to convert the dc generated by the PV panels to ac for most domestic and industrial use. For continuous availability of power during days of autonomy (low insolation or cloudy days), battery storage system and charge controller (for battery charge and discharge control) are required. inverter, charge controller, battery, components interconnection wires. The sizing processes considered the quality of solar irradiation of the geographical location, effect of temperature de-rating, efficiency of components, system voltage selection, days of autonomy and load demand (in watt-hour). A residence in Gaza town was chosen as a case study. The minimum electrical load of $7.875 \mathrm{kWh}$ per day, household, Finally excel program simulation was designed to satisfy calculation equations process and generalize the program.
\end{abstract}

Keywords- Electrical load demand, Photovoltaic system, Stand-alone, Solar irradiation, System sizing

\section{INTRODUCTION}

Harnessing solar energy to power electrical appliances starts by converting the energy from the sun to electricity. A photovoltaic (PV) cell converts sunlight into electricity. These cells are quite small and are connected together to form larger units called modules which can be connected to form even a larger unit called array. These arrays are connected in parallels and series formations to meet the required electricity demand. PV arrays produce electricity only when illuminated and is therefore necessary to employ a large energy storage system, most commonly a series of rechargeable batteries. Also to prevent harmful battery over-charge and over-discharge conditions and to drive AC loads and a charge controller and converters have to be implemented [2]. PV systems can be used to exploit the solar energy in almost all applications.

A stand-alone PV Systems are systems which use photovoltaic technology only and are not connected to a utility grid. The systems use the DC output of the PV modules to power DC loads, while a bank of battery is used to store energy for use when there is demand. The DC output of the batteries can be used immediately to run certain low DC Voltage loads such as lighting bulbs or refrigerators or it can be converted by an inverter to $\mathrm{AC}$ voltage to run AC-loads that constitutes most appliances. Off-grid PV system provides affordable electricity in area where conventional electricity grids are unreliable or nonexisting [8]. Schematic of a typical stand-alone photovoltaic system is shown below in fig1:

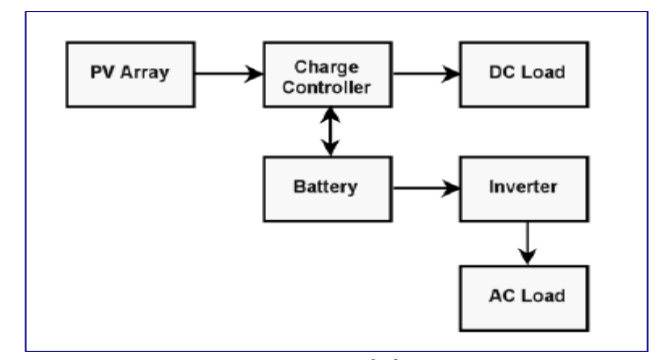

fig1: PHOTOVOLTAIC SYSTEMS -Standalone System

\section{METHODOLOGY}

The first task was to determine the system load. This load estimate is one of the key factors in the design and costing of the stand-alone PV system. The electrical loads available at the resident were profiled with their respective power ratings and average operation hours during the day noted to obtain the 
power demand in watt-hour per day. The result of the analysis obtained was used to determine the proposed stand-alone photovoltaic system components sizes.

\section{A. Resident Electrical Demand}

The household is a medium size resident not requiring very large quantity of electrical energy. Table 1 below shows the various electrical appliances and their load chat.:

Table 1-Electrical Load Demand for Residence:

\begin{tabular}{|c|c|c|c|c|}
\hline $\begin{array}{l}\text { Load } \\
\text { Description }\end{array}$ & Qty & Load Power(w) & $\begin{array}{l}\text { Hours wo } \\
\text { (Hris) }\end{array}$ & $\begin{array}{r}\text { Load Power } \\
\text { (W-h) }\end{array}$ \\
\hline Refrigerator & 1 & 260 & 6 & 1560 \\
\hline Television & 2 & 120 & 5 & 1200 \\
\hline Toaster & 1 & 750 & 0.4 & 300 \\
\hline $\begin{array}{l}\text { Fan } \\
\text { DVD Home }\end{array}$ & 4 & 65 & 4 & 1040 \\
\hline Theater & 1 & 60 & 4 & 240 \\
\hline Sat Decoder & 2 & 25 & 4 & 200 \\
\hline Laptop & 2 & 140 & 6 & 1680 \\
\hline Light & 8 & 36 & 4 & 1152 \\
\hline Electric Iroa & 1 & 1000 & o.s & 500 \\
\hline Clipper & 1 & 15 & 0.18 & 2.7 \\
\hline Total Power & & 2,471 & & $7,874.7$ \\
\hline
\end{tabular}

The residence under consideration consumes an approximate electrical load of $7.875 \mathrm{kWh} /$ day of electricity and daily watt power of $2.471 \mathrm{~kW}$.

\section{B. System Voltage Selection}

The operating voltage selection for a stand-alone system is dependent on the voltage requirement of the loads and the total current. However in a standalone PV system, the voltage is also dependent on the inverters that are available. When loads

\section{Pv Array Sizing}

The output power of $\mathrm{PV}$ array (PPv array) is determined by Equation. (1) [2]

$$
\mathrm{P}_{\mathrm{Pv} \text { array }}=\frac{\mathrm{E}_{\text {ld }}}{\eta_{\mathrm{B} .0} \times \mathrm{K}_{\text {Loss }} \times \mathrm{I}_{\mathrm{s}}} \times \mathrm{PSI}
$$

Where

Eld $=$ Average daily load energy in $\mathrm{kWh} /$ day,

Is = Average solar radiation in peak sun hour's incident for specified tilt angle in $\mathrm{kWh} / \mathrm{m} 2 /$ day.

PSI $=$ Peak solar intensity at the earth's surface $(1 \mathrm{~kW} / \mathrm{m} 2)$,

$\eta \mathrm{BO}=$ Efficiency of balance of system

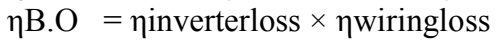

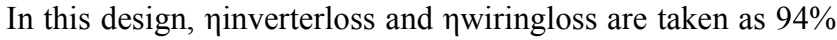
and $97 \%$ respectively

KLoss $=$ Factor determined by the different losses such as module temperature losses, circuit losses, dust, etc [4].

KLoss $=$ fman $\times$ ftemp $\times$ fdirt

Where,

fman $=$ manufacturer's tolerance ftemp $=$ Temperature derating factor fdirt $=$ De-rating due to dirt if in doubt, an acceptable de-rating would be $5 \%$ and is given by equation below, [4]

ftemp $=1-(\gamma($ Tcell.eff - Tstc $))$

Where,

$\gamma=$ Power temperature co-efficient per ${ }^{\circ} \mathrm{C}$

Tstc $=$ Cell temperature at Standard Test Conditions, in

Tcell-eff $=$ the average daily effective cell temperature in degrees Celsius $\left({ }^{\circ} \mathrm{C}\right)[14]$

Tcell.eff $=$ Ta.day +25

Where,

Ta.day = Daytime average ambient temperature in This average is about 28

Substituting this value into equation 5 above, we have 53

From equation 4 above,

ftemp $=1-(\gamma($ Tcell.eff - Tstc $))$

Using the selected manufacturers specification for the module, Tcell.eff $=53, \gamma=0.48 \% / \quad$ Tstc $=25$

ftemp $=1-[0.48(53-25)]=0.8656$

fman $=97 \%$

fdirt $=95 \%$

Substituting these into equation (3) we have

KLoss $=$ fman $\times$ ftemp $\times$ fdirt

$=0.97 \times 0.8656 \times 0.95$

$=0.7976$

From equation 2,

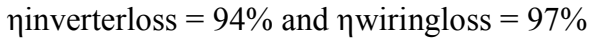

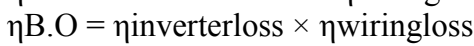

$=\quad 0.94 \times 0.97=0.912$

Substituting the above values into equation (1)

$$
\begin{aligned}
& P_{P_{v} \text { array }}=\frac{E_{l d}}{\eta_{\text {B.o }} \times K_{\text {Loss }} \times I_{S}} \times \text { PSI } \\
&=\quad(7.875 \times 1) /(0.912 \times 0.7976 \times 3.45)
\end{aligned}
$$

$=3.14 \mathrm{~kW}$

Number of Modules in Series

Determining the number of modules that would be in series $\mathrm{Nms}$ is designed to accommodate the system voltage required to power the entire load. This is achieved by dividing the designed system voltage Vsystem (usually determined by the battery bank or the inverter) with the nominal module voltage Vmodule at Standard Test Condition (STC) [2,14].

$\mathrm{Nms}=$ VSystem $/$ Vmodule

$\mathrm{Nms}=$ VSystem $/$ Vmodule $=\quad 48 / 24=2$ modules

\section{Numbers of Modules in Parallel}

A. The number of modules in parallel Nmp is found using the equation below, and is determined by the dividing the designed array output $\mathrm{PPv}$ array by the selected module output power Ppower and the number of module in series Nms [2].

$$
\begin{gathered}
\text { Nmp }=\text { Ppv array } / \text { Nms } \times \text { Pmodule } \\
\text { Nmp }=3.14 \times 10^{3} / 2 \times 180 \\
=8.7 \cong 9 \text { modules }
\end{gathered}
$$

The total number of modules is given by the product of the series and parallel modules, which is 
$\mathrm{Nmt}=\mathrm{Nms} \times \mathrm{Nmp}=2 \times 9=18$ modules

\section{Storage (Battery) System Sizing}

In the design of the capacity of the battery bank, it is necessary to consider some very important factors that determine the availability of power at all times, proper operation of the batteries, they include, the days of autonomy-days where there is little or no solar irradiation or cloudy days, allowable depth of discharge, possible battery loss, nominal system voltage of selected battery and estimated load energy in W-h [14]. The storage capacity can be calculated using the equation below [3,9].end of a sentence is punctuated outside of the closing parenthesis (like this).

$$
C_{B}=\frac{E_{l d} \times N_{a}}{D O D \times V_{\text {system }} \times \eta_{\text {bat }}}
$$

Where,

$$
\begin{gathered}
\mathrm{CB}=\text { Required minimum battery capacity } \\
\mathrm{Na}=\text { Number of days of autonomy } \\
\mathrm{DOD}=\text { Depth of discharge } \\
\mathrm{Eld}=\text { Average daily load energy in } \mathrm{kWh} / \text { day } \\
\text { Vsystem }=\text { System voltage } \\
\eta \text { bat }=\text { Battery efficiency }
\end{gathered}
$$

The battery selected is Rolls Series 4000 Deep Cycle batteries, T12 250, having the following characteristics, a capacity of $200 \mathrm{AH}$, and a voltage of $12 \mathrm{Vdc}$.

In this design, the days of autonomy is taken as 5 days, maximum allowable depth of discharge (DOD) taken as $50 \%$ and efficiency ( $\eta$ bat) of $85 \%$. Computing the battery capacity using the above variables gives us as below,

$\mathrm{CB}=7.875 \times 10^{3} \times 5 / 0.5 \times 48 \times 0.85=1930 \mathrm{Ah}$

Calculating the number of battery units required can be done using the equation below

$$
\begin{aligned}
& \text { Nbreq }=\mathrm{CB} / \text { Csel } \\
& \mathrm{CB}=1930 \mathrm{Ah} \\
& \mathrm{Csel}=200 \mathrm{Ah} \\
& \text { Nbreq }=1930 / 200 \\
& =9.6 \cong 12 \text { batteries }
\end{aligned}
$$

The approximate number of batteries required would be 12 batteries.

To determine the number of batteries in series, we divide the nominal system voltage with the battery voltage

$\mathrm{Nbs}=$ Vsystem / Vbat

Applying the above expression gives us the series as

$\mathrm{Nbs}=48 / 12$

$=4$ batteries
We also have to calculate the number of parallel by applying the formula below.

$$
\begin{aligned}
& \mathrm{NPb}=\text { Nbreq } / \mathrm{Nbs} \\
& \mathrm{NPb}=12 / 4=3
\end{aligned}
$$

The battery arrangement would be 4 series and 3 parallel combinations of $12 \mathrm{Vdc} 200 \mathrm{AH}$ Rolls 4000 series.

\section{INVERTER SIZING}

When designing a system inverter size, the actual power drawn from the appliances that will run at the same time must be determined as a first step. Also, we must consider the possibility of having large motors with very high starting current by multiplying their power by a factor of 3. Also to allow the system to expand, we multiply the sum of the two previous values by 1.25 as a safety factor [3].

$$
\begin{aligned}
& \mathrm{P}_{\text {invt }}=\left(\mathrm{P}_{\mathrm{rs}}+\mathrm{P}_{\mathrm{lsc}}\right) \times 1.25 \\
& \text { Where } \\
& \mathrm{P}_{\text {invt }}=\text { Inverter power rating } \\
& \mathrm{P}_{\mathrm{rs}}=\text { Power of } \\
& \text { appliances running } \\
& \text { simultaneously } \\
& \mathrm{P}_{\text {lsc }}=\text { Power of large } \\
& \text { surge current }
\end{aligned}
$$

This design does not have large surge current machines and as such, $\mathrm{P}_{\mathrm{lsc}}$ is zero and

$$
\begin{aligned}
& \mathrm{P}_{\mathrm{rs}}=2.471 \mathrm{~kW} \text { from table Table } 1 \\
& \mathrm{P}_{\text {invt }}=(2471+0) \times 1.25=3088.75 \mathrm{~W} \cong 3.50 \mathrm{~kW} \\
= & 3.5 \mathrm{kVA}
\end{aligned}
$$

From the above calculation, an inverter of $3.5 \mathrm{kVA}$ and 48VDC capacity was chosen. LS-3548 3500-W, 48-VDC, 220-Vac

\section{A. Charge Controller Sizing}

The charge controller regulates the flow of electricity from the solar modules to the battery bank. When the battery bank is low, the charge controller feeds all of the electricity from the array to the batteries. When the batteries reach a state of full charge, the charge controller stops or redirects the supply of electricity to prevent overcharging. Charge controllers are generally selected by their size or ability to control a given amount of current and by their operating voltage $[4,10]$. The rated maximum current of the charge controller is obtained by multiplying the short circuit current $\mathrm{I}_{\mathrm{sc}}$ of the modules connected in parallel by a safety factor $\mathrm{f}_{\text {safety }}$ to allow for short periods of high irradiance produced by momentary cloud enhancement. The rated maximum current is given by this expression below $[12,13]$ 


$$
\begin{array}{r}
\mathrm{I}_{\max }=\mathrm{N}_{\mathrm{mp}} \times \mathrm{I}_{\mathrm{sc}} \times \mathrm{F}_{\text {esafety }} \\
\text { We consider a safety factor } \mathrm{F}_{\text {safety }}=1.25 \\
\mathrm{I}_{\max }=9 \times 5.38 \times 1.25=60.525 \mathrm{Amps}
\end{array}
$$

Xantrex C60 Charge Controller was considered for this design. The number of charge controllers needed is given by the equation below

$$
\begin{aligned}
& \text { N€€=Imax } / \text { Iselected } \\
& \text { Where, } \\
& \text { Imax }=60.525 \mathrm{Amps} \text { and Iselected }=60 \mathrm{Amps} \\
& \text { NEefore, } \\
& \text { N }=60.525 / 60=1.00875 \cong 1
\end{aligned}
$$
Therefore,

Hence, 1 charge controller was selected

Sizing of System Cables

After sizing and selecting the major components, the interconnections wires are next. Selection of appropriate wire size and type enhances the reliability and performance of the photovoltaic system. The size of the wire must be capable of carrying the current at the operating temperature without excessive losses

\section{B. Cable Size: PV Module through Charge Controller to Battery}

The maximum current produces by the PV panels is given by equation 13 [12],

Imax $=\mathrm{Npb} \times$ Isc $\times$ Fsafety

The cross section that would be adequate for this current would be given by equation 15 [11]

Where,

$\mathrm{S}=\mathrm{L} \times \mathrm{I} / \gamma \times \mathrm{Vd}$

$\mathrm{Vd}=2 \%$ of maximum allowed voltage drop for the 2 series array PV

$=2 / 100 \times$ System Voltage at maximum power $=$

$0.02 \times 35.8 \times 2=1.432 \mathrm{~V} \mathrm{~L}$

$=$ distance from the PV array to the battery

through the charge controller

$=2 \times 15 \mathrm{~m}=30 \mathrm{~m}$

$\operatorname{Imax}=9 \times 5.38 \times 1.25=60.525 \mathrm{Amps}$

$\gamma=58 \mathrm{~m} / \Omega$. mm2 $=$ Conductivity of copper The cross section becomes

$\mathrm{S}=(30 \times 60.525) /(258 \times 1.432)=21.86 \mathrm{~mm}$
The optimum wire size for this current is \#3copper wire (AWG) which is equivalent to

$25 \mathrm{~mm} 2$ copper.

\section{Cable Sizing between Battery Bank and Inverter (Inverter Input Circuit Current)}

The DC wire from the battery to the inverter must withstand the maximum current at the input of the inverter. The maximum current carrying capacity of the cable is the continuous inverter input current rating when the inverter is producing rated power at lowest input voltage and is given by equation 16 below [12].

$\mathrm{I}=$ Pinvt $/ \mathrm{VD} € \times$ invt

Where,

$\eta$ invt $=$ inverter efficiency $=94 \%$

Pinvt $=3.5 \mathrm{kw}$

$\mathrm{VD} €=48 \mathrm{~V}$, at lowest possible of $-2 \mathrm{Vdc}$,

$\mathrm{I}=3.5 \times 10^{3} / 46 \times 0.94$

$=80.9 \mathrm{Amps}$

A minimum wire of \#2 copper wire (AWG) equivalent to $35 \mathrm{~mm} 2$ is required to terminate the battery and inverter. This selection takes into consideration the possibility of having $2 \mathrm{Vdc}$ drop at the inverter input.

\section{Cable Size between Inverter and Load}

The ac-wire from the inverter to the electric panel of the residence must withstand the maximum current that the inverter can produce at full load. This current is given by the following formula for a rated ac-voltage (Vac) of 220V [12].

Imaxinv $=$ Pinvt $/ \mathrm{Vac} \times \mathrm{pf}$

Where,

$\mathrm{pf}=$ power factor $=0.8$

I $\max$ inv $=3500 / 220 \times 0.8$

$=19.9$ Amps

An optimum wire size of $\# 10$ copper wires (AWG), equivalent to $6 \mathrm{~mm} 2$ was considered for this design.

The complete system Excel Program Simulation was designed to get the PV modules, Batteries, inverters characteristics, Charge controller and Cable Sizing and attached file scanned is supported as clarified in Table 2 .

Table 2: PV-Stand Alone System design by Scanned Excel Program Simulation: 


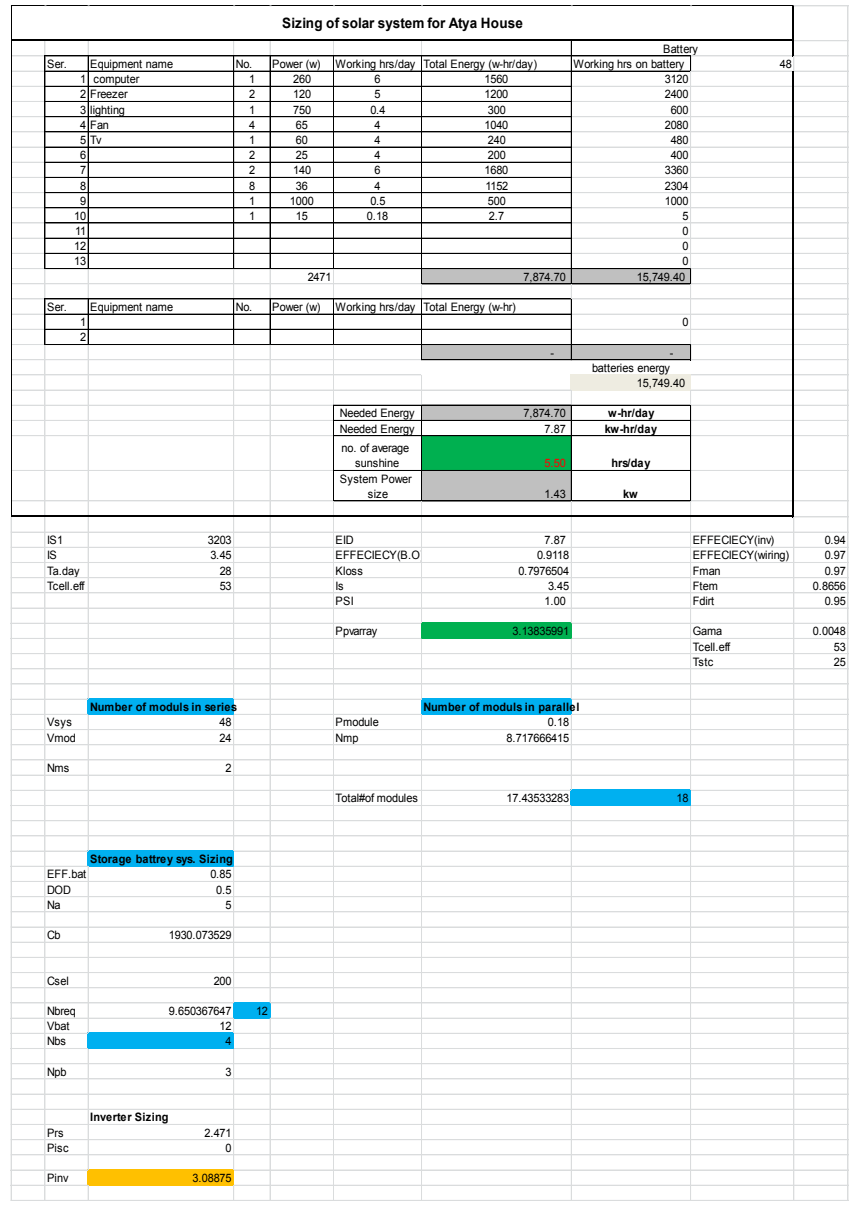

\section{CONCLUSION/RECOMMENDATION}

The proposed stand-alone PV system was designed based on estimated load demand in watt-hour rating of appliances. The result of the estimated daily demand is shown in Table-1. The result of which amounted to $7.875 \mathrm{kWh} /$ day. The detailed result of the design and component sizes are in Table 3 comprising of 18 ENP Sonne 180W, 24V PV modules which is capable of producing an array power of $3.14 \mathrm{~kW}$. The PV array design is composed of 9 parallel and 2 series so as to meet the desired current and voltages for the load system. The storage system consideration was designed to meet the load demand. Total of 12 numbers of $12 \mathrm{Vdc} 200 \mathrm{AH}$ Rolls 4000 series T12 250 with a bank capacity of $1930 \mathrm{AH}$, having 4 series and 3 parallel battery combinations. The total current from the PV arrays is 60.525Amps and Xantrex C60 Charge Controller was selected for this design. The rating of the designed inverter for the conversion of dc to ac is $3.5 \mathrm{~kW}$, and Latronic Ls-3548 3500-W 48Vdc inverter was selected. The wire sizing considered the current carrying capacity of each of the components. Between the PV panel through Charge controller and the battery which carries a current of 60.525Amps, \#3copper wire (AWG) which is equivalent to
$25 \mathrm{~mm} 2$ copper wire was selected. From the design calculation, the optimum wire of \#1 copper wire (AWG) equivalent to $35 \mathrm{~mm} 2$ is required to terminate the battery and inverter. While feeding the load distribution would require an optimum wire size of \#10 copper wires (AWG), an equivalent of $6 \mathrm{~mm} 2$ which is adequate to carry the 19.02Amps the inverter is capable of delivering at full load. The complete system Excel Program Simulation was designed to get the PV modules, Batteries, inverters characteristics, Charge controller and Cable Sizing and attached file scanned is supported.

\section{ACKNOWLEDGMENT (Heading 5)}

We reveal deep thanks to Gaza University which supports us in all facilities and put university laboratory for solar cell under our research and experiences and gives us coordination with administration of university and Palestine Broadcasting Television

\section{REFERENCES}

[1] Abd El-Shafy A. Nafeh (2009) "Design and Economic Analysis of a Stand-Alone PV System to Electrify a Remote Area Household in Egypt" The Open Renewable Energy Journal, 2009, Vol. 2, PP33-37.

[2] Amal, A. Hassan et al. (2010) "Stand-Alone Photovoltaic System for an Emergency Health Clinic" International Conference on Renewable Energies and Power Quality (ICREPQ). Granada (Spain) $23^{\text {rd }}$ to $25^{\text {th }}$ March2010.

[3] Assad Abu-Jasser, "A Stand Alone Photovoltaic System, Case Study: A Residence in Gaza", Journal of Applied Sciences in Environmental Sanitation. Vol. 5, 2010 PP: 81-91

[4] Clean Energy Council (CEC), "Grid Connected PV Systems Design Guidelines for Accredited Designers" Issue 3 July, Update November 2009.

[5] Engr. C.O. Osueke et al (2011) "Design of a Solar Power System for Optimal Output" International Journal of Advanced Engineering Sciences and Technologies. 2011, Vol. No 11, Issue No. 1 PP 232-237

[6] Federal Ministry of Power and Steel Federal Republic of Nigeria "Renewable Electricity Action Program (REAP)" International Centre for Energy, Environment and Development (ICEED) December 2006.

[7] Federal Republic of Nigeria National Bureau of Statistics "Annual Abstract of Statistics, 2010

[8] http://re.jrc.ec.europa.eu/pvgis/ PVGIS (c) European Communities, 2001-2012

[9] Ishaq M., Ibrahim U.H., Abubakar, H. (2013) "Design of an Off Grid Photovoltaic System: A Case Study of Government Technical College, Wudil, Kano" International Journal of Scientific and Technology Research Volume 2, Issue 12, December 2013. PP 175-181

[10] Khaled Bataineh, Doraid Dalalah, (2012) "Optimun Configuration for Design of Stand- Alone PV System" Scientific Research. Smart Grid and Renewable Energy, 2012, 3, PP139-147.

[11] Lisardo Recio Maillo (2013) "Application Note-Optimal Cable Sizing in PV System: Case Study" Leonardo Energy, European Copper Institute Copper Alliance, Publication No Cu0167. Issue 02, June 2013.

[12] National Electrical Code Handbook, Twelfth Edition International Electrical Code ${ }^{\circledR}$ Series. Article 690 (2011)

[13] Sandia, (1995), "Stand-Alone Photovoltaic Systems: A Handbook of Recommended Design Practices", Sandia National Laboratories Albuquerque New Mexico. PP: 1-B53

[14] SEIAPI Sustainable Energy (2012) "Off Grid PV Power Systems: System Design

[15] Guidelines" Pacific Power Association. Issue 1 September 2012 